\title{
IAMJ
}

INTERNATIONAL

AYURVEDIC

MEDICAL JOURNAL

\section{APPROACHING SENSORY NEURAL HEARING LOSS THROUGH AYURVEDA - A SINGLE CASE REPORT}

\section{Syed Munawar Pasha}

Associate Professor \& H.O.D

Department of PG Studies in Shalakya Tantra

Government Ayurveda Medical College, Bengaluru-560009, Karnataka, India

Corresponding Author: shalakyagamc21@gmail.com

https://doi.org/10.46607/iamj2009032021

(Published online: March 2021)

Open Access

(C) International Ayurvedic Medical Journal, India 2021

Article Received: 02/02/2021 - Peer Reviewed: 14/02/2021 - Accepted for Publication: 17/02/2021

Check for updates

\begin{abstract}
Objectives: Sensory Neural Hearing Loss (SNHL) is caused by damage to the structures of the inner ear or the auditory nerve. It is the cause of more than 90 percent of hearing loss in adults. It can interfere with your ability to communicate if not properly managed. SNHL has no permanent cure, in modern medication it is managed by application of Hearing aid or surgical intervention like cochlear implant depending upon the condition. Thus, here we are aiming for the management of SNHL without surgical intervention and improving the condition through the application of Ayurveda. Methods: A 60- year old elderly male adult approached OPD of SJIIM Bengaluru, complaining of decreased hearing in both the ears along with tinnitus since 2months. He was taken in for treatment after assessment. Result: After 6 months of treatment there was relief from tinnitus and improvement in hearing. Conclusion: There will be halt in the progression of the disease as well as improvement in hearing by following the Ayurvedic protocol, which will in return also improve the quality of life.
\end{abstract}

Keywords: Sensory Neural Hearing Loss, Badhirya, Karnapurana. 


\section{INTRODUCTION}

Hearing loss is a common problem caused by noise, aging, disease and heredity. People with hearing loss may find it hard to have conversations with friends and family. Approximately one in three people between the ages of 60 and 74 has hearing loss ${ }^{1}$. Sensory Neural Hearing loss results from lesions of the cochlea, $8^{\text {th }}$ nerve or central auditory pathways. It can be congenital or acquired. It occurs due to damage to the inner ear by causing wear and tear on the hairs or nerve cells in the cochlea that send sound signals to the brain. When these hairs or nerve cells are damaged or missing, electrical signals aren't transmitted as efficiently, and hearing loss occurs. Common symptoms associated with Sensory Neural Hearing loss are dizziness, tinnitus, trouble hearing high pitched sounds or trouble hearing sounds when there's background noise, muffled sounds and voices.

Types of SNHL are:-

a) Bilateral Sensorineural Hearing Loss

b) Unilateral Sensorineural Hearing Loss

c) Asymmetrical Sensorineural Hearing Loss ${ }^{2}$

The most common options for this condition are hearing aids and cochlear implants for compensating hearing loss; research is now going on the field of gene therapy for hearing loss ${ }^{3}$. Thus, it is not giving satisfactory result for patients, thus there is a need for a treatment protocol for the improvement of the condition as well as maintaining its progression. Here comes the role of Ayurveda. Main principal of Ayurveda being "prevention better than cure", we can implement Ayurveda protocol in our daily life thus improving and restricting the progression as well as preventing the condition from occurring. Most of the symptoms are similar to Badhirya, thus we can manage it according to its treatment line.

\section{Materials and Methods}

Case Description: Date: 2/06/2020, Age: 60 years, Sex: Male, Occupation: Clerk in Government Office, Place: Bengaluru

Chief complaints: Patient complaints of decrease of hearing in both the ears, Along with tinnitus since 3 month.
History of present Illness: Patient was apparently normal before 3 months; gradually he started experiencing ringing type of sound in both the ears along with difficulty in hearing sound, thus he approached an ENT physician and he was advised to use hearing aid, but the patient wanted to try Ayurveda thus he approached our OPD.

History of Past illness: No known complaints of $\mathrm{DM} / \mathrm{HTN}$.

Family History: Nothing Specific

Personal History: Appetite: Good, Sleep: Sound, Bowel: Once a day, Micturition: 4-6 times a day, Diet: Mixed

Ashta Stana Pareeksha: Nadi: 70min, Mutra: 45times/day, Mala: Prakrutha, Jihwa: Alpa lipta, Shabda: Prakrutha, Akriti: Krisha

Examination: As shown in the table no: 1

General Examination: Respiratory system: No wheezing on auscultation, CVS: No murmurs on auscultation, Per abdomen: on, palpitation nothing specific. Pulse rate: $70 / \mathrm{min}, \mathrm{BP}-130 / 78 \mathrm{~mm} / \mathrm{hg}$, Weight- $68 \mathrm{~kg}$, Height: $172 \mathrm{~cm}$

Investigations: Pure Tone Audiometry was performed as shown in figure.1.

Diagnosis: Badhirya, Moderately Severe Sensory Neural Hearing Loss.

\section{Treatment}

The patient was administered with Ayurvedic treatment for a period of 6 months as shown in table no.2 and was advised to follow pathya and avoid apathya, which is shown in table no.3.

\section{Results}

After following Ayurvedic Treatment and Dinacharya for 6 months patient felt subjectively much improvement, during the first 2 months of treatment tinnitus was reduced to mild and after the completion of 5 months he was completely relieved from tinnitus. The changes in hearing levels are shown in the figure 2. Where PTA in bilateral ear's has come to 48.3 dBHL from $60 \mathrm{dBHL}$. 


\section{DISCUSSION}

Sensory Neural Hearing Loss could be correlated to Badhirya according to the signs and symptoms. Badhirya occurs due to the Dushti/ vitiation of Vata and Kapha Doshas. According to Vagbhata if the Karna Nada is not treated properly or the person who is having Karna Nada doesn't follow Pathya, it will lead to Badhirya ${ }^{5}$. Here the patient is old and is at the age of VataPrakopa, which is one of the main reasons for the occurrence of the disease. Treatments mentioned for Badhirya in classics are Vata Vyadhi hara Chikitsa, which includes Snehapana, Virechana, Nasya and Karnapoorana ${ }^{6}$.

\section{Probable Mode of Action:}

1. Deepana and Pachana: was done by giving Chitrakdi vati to remove Ama avastha.

2. Snehapana: Dhanvantaram Ghritha is having sroto sanga hara, Balya as well as Vata Kaphahara action? ${ }^{7}$.

3. Virechana: was given with Trivrut Lehya. Natural detoxification will lead to expulsion of Dooshita Doshas, thus by clearing the pathway and normalising the direction of Vata $^{8}$.

4. Anutaila Nasya: Nasya will easily spread into Shira and after reaching sringataka marma it removes the avaranatva of Kapha dosha and it does the nourishment of Urdhwa jatru pradesha or the associated sense organs. Anu taila is tridosha hara in action it does influence on limbic system and circulation and produces the action of excitation 9

5. Karnapoorana: Bilwadi taila is indicated in Badhirya Chikitsa. And it has Vatahara action. Acoustic nerve gets nourished by karnapoorana ${ }^{10}$.

6. Shiro Pichu: Ksheera Bala taila helps in bringing down the vitiated Vayu. Thus, the concentrated oil having theekshna and ushna property gets absorbed through the scalp skin due to the longer duration of the contact in Shiro pichu ${ }^{11}$.

7. Orally: a) Sarivadi vati is one of the best Rasayana drug for karnendriya as it does Srotho shodhana and Vata hara action ${ }^{12}$.

b) Dashamoola Rasayana: It is mentioned in Prathishyaya hara Chikitsa thus we can use it for
Badhirya. It does Dhatu poshana and Vata Kapha hara action $^{13}$.

\section{CONCLUSION}

Sensory Neural Loss is one of the main hearing loss which is faced by the people of old age, thus there is no proper treatment protocol for it nor any prevention plan, thus Ayurveda provides it a proper Prevention plan by following Pathya and Dinacharya. And helping to improve the condition by various treatment like Nasya, Karnapoorana and internally Rasayana therapy, which is evident in this case report.

\section{REFERENCES}

1. What is Sensory Neural Hearing Loss. Aimee Eyvazzadeh. Healthline. March 102020. https://www.healthline.com/health/sensorineuralhearing-loss\#sudden-sensorineural-hearing-loss

2. PL Dhingra. Shruti Dingra. Diseases of Ear Nose and Throat \& Head and Neck Surgery. Elsevier Publications. New Delhi. $7^{\text {th }}$ Edition. 2018. pp 35.

3. Hearing Loss. Mayo Clinic. https://www.mayoclinic.org/diseases-

conditions/hearing-loss/symptoms-causes/syc20373072

4. Tripathi Brahmanand Agneevesha. Charaka. Dridhabala. Charaka Samhitha. Sutra Sthana.(30/26).Varanasi. Chaukambha Subharati Prakashan.2014.pp 456.

5. Susrutha. Susrutha Samhitha English translation by prof. K. R. Srikantha Murthy. Chaukambha Orientalia. Varanasi. Vol-3.First Edition.2002.(20/8).pp 98.

6. Susrutha. Susrutha Samhitha English translation by prof. K. R. Srikantha Murthy. Chaukambha Orientalia.Varanasi.Vol-3.First

Edition.2002.(21/38).pp 130

7. Vagbhata. Ashtanga Hridaya. Chikista Sthana. (12/1923).Aruna Dtta. Reprint 2010. Chaukambha Orientalia. Varanasi. Vol-2. Second Edition.pp454.

8. Vagbhata. Ashtanga Hridaya. Kalpa Sthana. (2/9). Aruna Dtta. Reprint 2010. Chaukambha Orientalia. Varanasi. Vol-2. Second Edition.pp813.

9. Vagbhata. Ashtanga Hridaya. Sutra Sthana. (20/37). Aruna Dtta. Reprint 2010. Chaukambha Orientalia. Varanasi. Vol-2. Second Edition.pp293.

10. Susrutha. Susrutha Samhitha English translation by prof. K. R. Srikantha Murthy. Chaukambha 
Orientalia.Varanasi.Vol-3.First

Edition.2002.(21/35).pp 130

11. Kiran Raj. A Conceptual Study of Shiropichu in the Management of Shirashoola. International Ayurvedic Medical Journal. May.2017. 5(5). pp1594.

12. Krushna Chandra Chunekar. Bhavamishra. Bhavaprakash Nighantu. Hindi Translation. Punah
Mudrit. 2013. Chaukambha Orientalia. Varanasi. Guduchyadi Varga.2/49.pp213.

13. K V Krishnan Vaidyar.Sahasra Yogam.Vidyarambham Publications.Alapuzha.30 ${ }^{\text {th }}$ Edition.2011.pp 134.

Table 1: Examination

\begin{tabular}{|l|l|l|}
\hline Sl.no: & Examination & Findings \\
\hline 1. & Otoscopy & 1)EAC: B/L clear, 2) TM: B/L intact \\
\hline 2. & Rinne's test & Positive.AC $>$ BC \\
\hline 3. & Weber's test & Cant consider \\
\hline 4. & Audiometry & $\begin{array}{l}\text { B/L Moderately severe Sensory Neural Hearing Loss } \\
\text { PTA:- Right ear:- 60dBHL, Left ear:- 56.7dBHL }\end{array}$ \\
\hline 5. & Tinnitus & Subjective \\
\hline
\end{tabular}

Table 2: Treatment

\begin{tabular}{|c|c|c|c|c|}
\hline SI. No. & Treatment & Medicine & Mode of administration & Duration \\
\hline 1. & Deepana and Pachana & Chitrakadi Vati & 1 tid before food & 3 days \\
\hline 2. & Snehapana & Dhanvantharam Ghrita & $\begin{array}{l}>1^{\text {st }} \text { day- } 10 \mathrm{ml} \text { before food } \\
>2^{\text {nd }} \text { day- } 20 \mathrm{ml} \\
>3^{\text {rd }} \text { day- } 50 \mathrm{ml} \\
>4^{\text {th }} \text { day- } 70 \mathrm{ml} \\
>5^{\text {th }} \text { day- } 90 \mathrm{ml} \\
>6^{\text {th }} \text { day- } 110 \mathrm{ml} \\
>7^{\text {th }} \text { day- } 130 \mathrm{ml}\end{array}$ & 7 days \\
\hline 3. & Snehana and Swedana & Ksheera bala taila & $\begin{array}{l}\text { Patient was advised to do Abhyanga and } \\
\text { have hot water bath. }\end{array}$ & 1 day \\
\hline 4. & Virechana & Trivrit lehya & $30 \mathrm{gm}$ before food & 1 day \\
\hline 5. & Pratimarsha Nasya & Anutaila & 2 drops to each nostrils in early morning & 6 months \\
\hline 6. & Karnapoorana & Bilwadi Taila & $\begin{array}{l}1 \text { sitting of } 8 \text { drops for } 7 \text { days once in } \\
3 \text { months. }\end{array}$ & 3 months \\
\hline 7. & Shiro pichu & Ksheera bala taila & 1 sitting of 7 days. & 7 days \\
\hline 8. & Oraly & $\begin{array}{l}\text { 1) Sarivadi vati. } \\
\text { 2) Dashamoolarasaya } \\
\text { na }\end{array}$ & $\begin{array}{l}1 \mathrm{BD} \text { after food } \\
1 \mathrm{tbsp} \text { at night after food }\end{array}$ & 6 months \\
\hline
\end{tabular}

Table 3: Pathya and Apathya

\section{Do's}

$>$ Not doing strenuous exercises

$>$ Not taking head bath

> Maintaining Brahmacharya

Not doing excess talking.

$>$ Intake of Mamsarasa(soup)

$>$ Indulging ghee and milk in your diet

$>$ Having good soft bed for sleeping

$>$ Having correct amount of salt in your diet.

\section{Don'ts}

$>$ Head bath

$>$ Exercise

$>$ Sorrow or sadness

$>$ Doing exertive work

$>$ Exposure to excessive cold

$>$ Usage of Ruksha or Kashaya Bhojana.

$>$ Usage of sharp objects for itching or removing of wax in ear. 
Figure 1: Before treatment
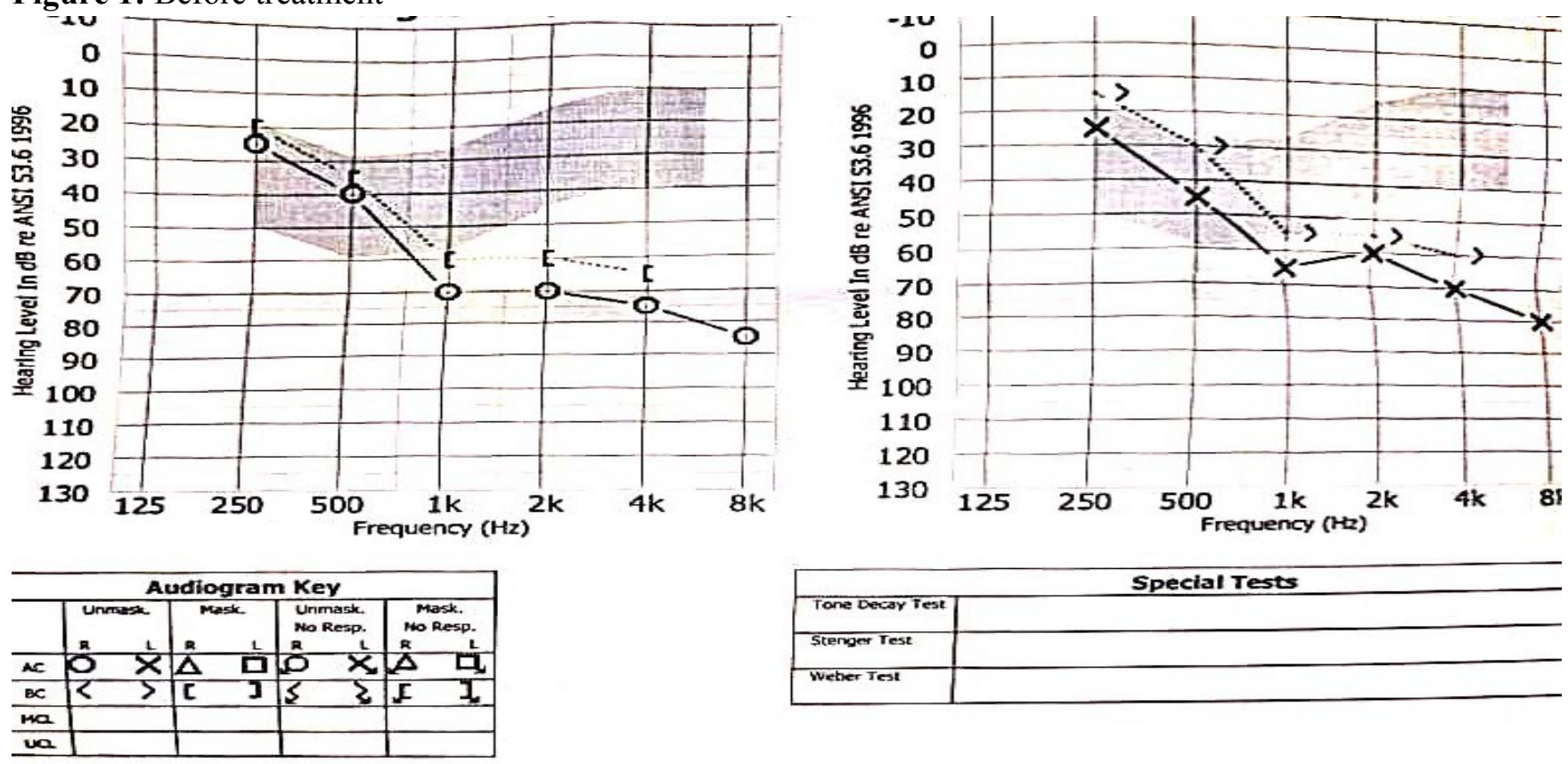

\begin{tabular}{|l|l}
\hline \multicolumn{2}{|c}{ Special Tests } \\
\hline Tone Decar Test & \\
\hline Stenger Test & \\
\hline Weber Test & \\
\hline
\end{tabular}

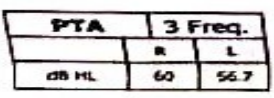

Session Comments:

INTERPRETATION:

PURE TONE AUDIOMETRY RESULTS

BILATERAL MODERATELY SEVERE SLOPING SENSORINEURAL HEARING LOSS.

RECOMMENDATION:

ENT REVIEW

HEARING AID USAGE
FOLLOW UP
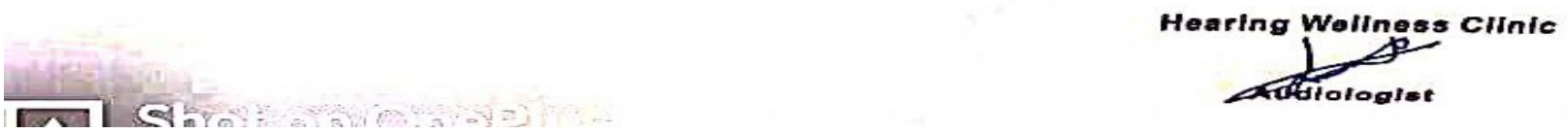

Figure 2: After treatment 

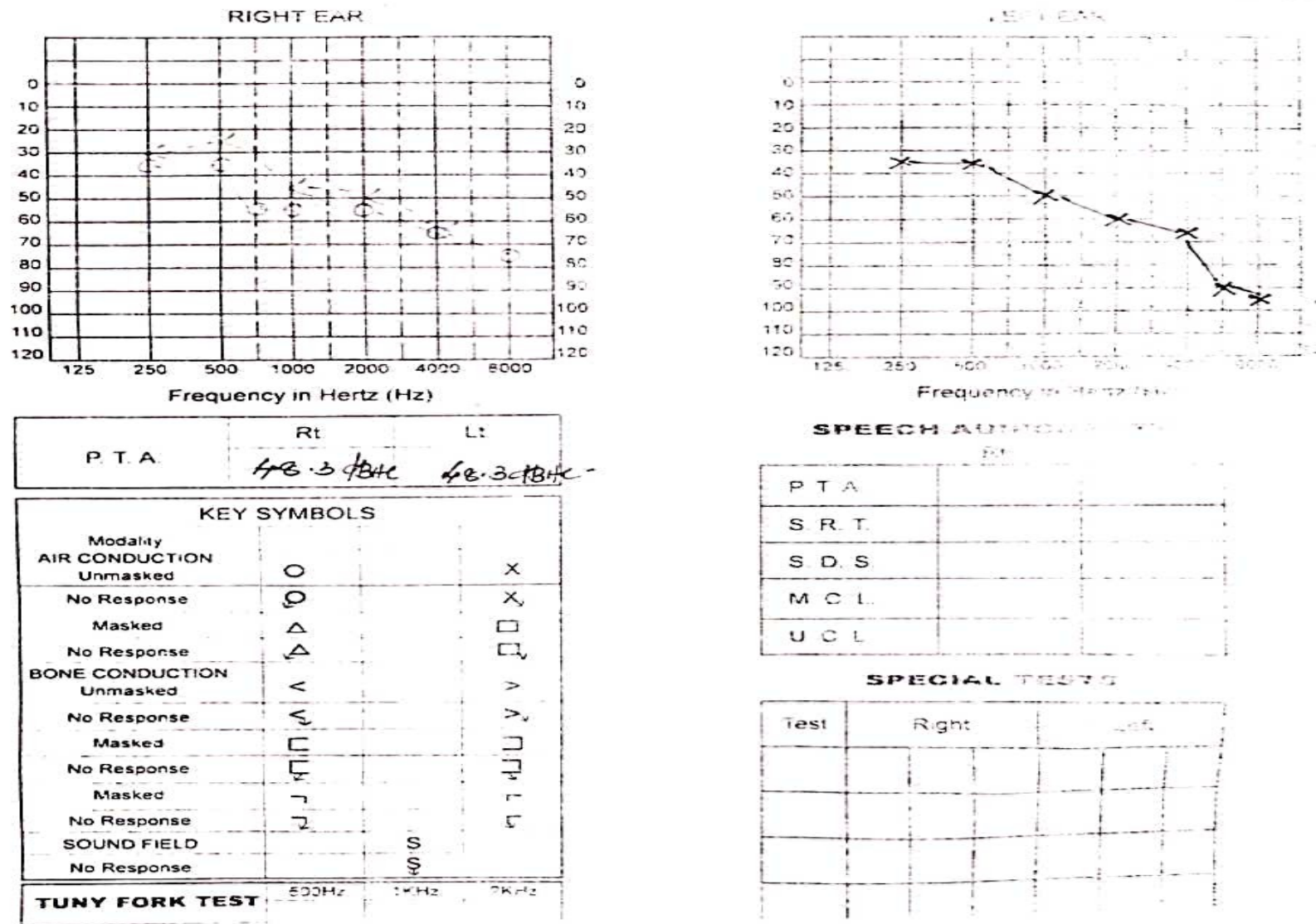

\section{Source of Support: Nil \\ Conflict of Interest: None Declared}

How to cite this URL: Syed Munawar Pasha: Approaching Sensory Neural Hearing Loss Through Ayurveda - A Single Case Report. International Ayurvedic Medical Journal \{online\} 2021 \{cited March, 2021\} Available from: http://www.iamj.in/posts/images/upload/641_646.pdf 